\title{
TWITTER AS POLITICAL COMMUNICATION PLATFORM IN ELECTION CAMPAIGNS IN GHANA
}

\section{AKWASI BOSOMPEM BOATENG}

School of Communication Studies, North-West University, South Africa

\begin{abstract}
This article argues that political parties need to emphasise relationship building as part of their election communication to ensure the sustainability of the party. This is based on the premise that they should also engage in two-way communication. Social media such as Twitter provides the opportunity for engagement and two-way communication with the electorate. It is therefore not surprising that the use of social media by political parties is becoming a common phenomenon. This is also the case in Ghana where political parties are increasingly using social media in their campaign communication. The question however remains whether political parties are using the interactive capabilities of social media or merely focusing on one-way communication messages. Against this background, this article examines the use of social media in intra-party elections of the New Patriotic Party and the National Democratic Congress in Ghana during the 2018 elections. By means of content analysis, the messages on the political parties' Twitter platforms during their national executive elections in 2018 were analysed. The findings indicate that the New Patriotic Party and the National Democratic Congress used Twitter for one-way communication with stakeholders and the public. The messages mainly informed the public about their activities and programmes, rather than interacting with them to develop mutually beneficial relationships. The political parties made tweets infrequently to users and followers on Twitter. Therefore, the political parties did not utilise the interactive capabilities of the social media platform to engage with the electorate and build relationships.
\end{abstract}

KEYWORDS: Political Communication, Social Media, Twitter, Election Campaigns, Stakeholder Relations.

Received: Jun 15, 2021; Accepted: Jul 05, 2021; Published: Jul 22, 2021; Paper Id.: IJCMSDEC20213

\section{INTRODUCTION}

Broadly speaking political communication is defined as the use of symbols and language by politicians and the media on the one hand, and behaviour of citizens, on the other hand, to elicit intended and unintended effects on the political cognition, attitudes and behaviours of individuals, or influence outcomes of public policies of countries (Perloff, 2014). Traditionally, this has been done by means of press conferences, commentaries and interviews in the media for publicising political messages, opinions, manifestoes, policies and programmes (Asah-Asante, 2015; Oye, 2009; Debrah, 2005). This consisted mainly of one-way communication from political role players to the public. However, from a relationship perspective, Muhingi, Agonga, Mainye, Mong'are and Maranga (2015, p. 57) posit political communication as an interactive process that involves the exchange of information and messages among "political parties, news media and the public". This could enhance relations or create conflicts of "interests and ambitions between individuals, groups and political structures in the process of attaining power," or perhaps holding on to power. The relationship perspective is especially important when investigating electoral communication as a form of political communication (Klingemann \& Römmele, 2002). 
The main aim of election communication is to garner votes to ensure the sustainability of the party (Denton, Trent \& Friedenberg, 2020; Kiyohara, Maeshima \& Owen, 2018) and by implication sustainable democracy. This implies that political parties not only have to persuade voters to vote for them during elections, but also need to establish long term relationships and create alliances with diverse groups and people with similar goals and interests (Strömbäck \& Kiousis, 2014). The need for engaging with the public and electorates between elections to enable them to secure more votes at elections encourage political parties to focus on relational and reputational factors in communication and campaigns (Dragaset, 2014; Strömbäck \& Kiousis, 2014, 2013). The interactive nature of social media ideally provides the opportunity for two-way communication, and also for electoral communication. It is argued in this article that social media including Facebook and Twitter could provide interactive avenues for direct interpersonal engagements for mutually beneficial relationships between political role players (Dragaset, 2014; Strömbäck \& Kiousis, 2014; Grunig, 2001).

Social media have become important communication platforms in recent election campaigns as is evident from the election and re-election of President Barrack Obama (Borah, 2016). Social media were mainly used to advance the political agendas of parties (Dzisah, 2020; Tettey, 2017), membership drives, political marketing, advertising and canvassing votes (Gyampo, 2017; Penplusbyte, 2017), but not necessary to engage the electorates. This observation is noted by scholars (see Mutsvairo \& Ragnedda, 2019; Windeck, 2011; Riaz, 2010), in that social media activities and engagements are not significantly driving democracy and participation in African countries including Ghana. This might be because the interactive nature of social media also poses problems for political parties because they cannot easily determine their narratives, particularly during elections.

However, it is argued in this article that to enable the long term sustainability of the political party, and by implication democracy, it is necessary to utilise the interactive abilities of social media to enable direct engagements with the electorate and political role players (see Denton, Trent \& Friedenberg, 2020; Kearney, 2017; Dillard, 2008). Political parties globally, including Ghana, should thus be taking advantage of social media by using these platforms in their activities, programmes and campaign communication. It is against this backdrop that the current article explores how the New Patriotic Party and the National Democratic Congress used Twitter as social media platform during the 2018 intraparty election campaigns. In doing so, the following research question is addressed:

- How do the New Patriotic Party and the National Democratic Congress use Twitter as a political communication platform in election campaigns in Ghana?

\section{Literature Review: The Changing Nature of Electoral Communication}

As argued above, a relationship approach in political communication has become more important in modern day politics to ensure the sustainability of political parties. Relationship management is a "management function that establishes and maintains mutually beneficial relationships between organisations and their publics on whom their success or failure depends" (Cutlip, Center \& Broom, 1994). Research has indicated that two-way symmetrical communication is the ethical and effective way to establish mutually beneficial relationships. This is because two-way symmetric communication provides stakeholders and the public with the opportunity to exchange information and feedback for support and cooperation. Mutually beneficial relationship dimensions focus on trust, openness and involvement of organisations' stakeholders and the public in decision-making via two-way communication (Grunig, 2001; Cutlip et al., 1994). 
Given the need for two-way communication in political communication and election campaigns, social media platforms could contribute to the quality of engagements by governments and political parties with citizens and electorates (Boateng, McCracken \& Lubombo, 2020; Kreiss, 2016; Kalsnes, 2016; Larsson, 2015). The use of social media in engaging and conversing with citizens beyond traditional mass media provides political parties and politicians with access to communities, which enables interactions with their constituencies and the broader public (Ndlela \& Mano 2020; Muhingi et al., 2015; Beciu, 2011; Mayfield, 2008). It is therefore expected that social media would become increasingly important in political communication (Ndlela \& Mano, 2020; Dzisah, 2020; Sweetser, 2011; Lilleker \& Jackson, 2011). This is also the case in Africa as is evident from several studies analysing the use of social media in elections (Ndlela \& Mano, 2020, Boateng et al., 2020). These studies confirmed that social media contribute to political engagements, mobilisation and participation (Hoffmann \& Suphan, 2017; Beciu, 2011; Mayfield, 2008), and campaign fund-raising (Borah, 2016).

When looking at the literature it would seem that we can summarise the functions of social media in political communication as soliciting support, fund-raising and interactive engagement with the aim of building relationships. Traditionally, soliciting support has been one of the most important outcomes of electoral communication. Social media can also support this function (Enli,2017; Borah, 2016; Penplusbyte, 2017). The unique abilities of social media provide political role players with unique opportunities to influence the electorate, by means of information acquisition via political marketing and advertising (Biswas, Ingle \& Roy, 2014). It is also evident that social media as interactive platforms enable political parties to raise funds from their supporters and the public, especially during election campaigns (Gyampo, 2017; Borah, 2016; Penplusbyte, 2017). This was also the case in Ghana where political parties and their presidential candidates used social media platforms to solicit funds and donations from the general public during the 2012 and 2016 general elections (Dzisah, 2020; Gyampo, 2017; Penblysbyte, 2017).

The real value of social media as a political communication platform lies in the interactive capabilities contributing to relationship building. Social media promote openness for meaningful political communication and discourses in mobilising support for political activities. The relational resource goals of political parties on social media could be achieved if the personal rewards, emotional support and gratification that are sought by users and visitors of their social media platforms are addressed through interactions. For example, while Facebook via its social networking features provides a means of getting and staying in touch with people and establishing relationships, Twitter as a micro-blogging platform allows users to engage people and track news and discussions (Volders, 2013; Lilleker \& Jackson, 2011).

With their potential to advance relational political engagements, political role players have not only used social media communication to mobilise support, but to widely relate to different stakeholders and the general public (Boateng, 2019; Dragaset, 2014; Gonçalves, 2014). Political parties and campaigners could take advantage of their social media connections and get users talking about them and share their policies and programmes to win votes in elections. With social media, electorates could believe that they have some intimate relationships with political role players online, which may influence their voting behaviour because political parties control, craft and communicate convincing messages on these platforms to influence the public (Biswas et al., 2014).

The categories of Gong and Lips (2009) are relevant and suitable for this research in analysing data from the Twitter platforms of political parties. This article uses Gong and Lips' framework because the categories focus on social media communication relationships and situate the benefits of different forms of engagements in developing, sustaining 
and enhancing long term relations between political role players and the electorates. These content categories demonstrate how two-way versus one-way communication could be used in relating with the public. Tweets are messages published on Twitter (Volders, 2013; Lilleker \& Jackson, 2011). There are different types of tweets on Twitter. These messages could be texts or multimedia containing pictures, audio and video formats (Coulombe, 2004).

Information provision messages draw the attention of audiences to particular news, events and situations in the form of news releases, press statements and policy statements (Gong \& Lips, 2009). Messages that are targeted at identified audiences and specific groups of the public, such as opponents and segments of voters are target campaigning (Gong \& Lips, 2009). Information provision and targeted campaigning involve one-way communication and persuasions in canvassing for votes during elections. Messages that are aimed at interaction could be done through question and answer sessions, as well as responses to enquiries from audiences to promote conversations and sustain relationships. Question and answer sessions allow social media users the chance to ask questions, while responses to enquiries entail responding to issues raised by audiences (Gong \& Lips, 2009). Interactive and multi-media chats promote engagements, especially through likes, re-tweets, comments, replies and shares, among others on Twitter, to agree, endorse, build trust and enhance mutually beneficial relationships. Therefore, the messages tweeted on these social media platforms should be interactive to promote relationships.

\section{RESEARCH METHODS}

\section{Content analysis}

Content analysis was done to explore how the political parties in Ghana use social media in communication practices and intra-party election campaigns.

\section{Sampling}

The New Patriotic Party and the National Democratic Congress were selected for this study because they have been participating in elections since 1992 and therefore are established parties in Ghana. The focus of this study is the intraparty elections in 2018. The New Patriotic Party was the first to hold its elections from 6 July to 8 July 2018, followed by the National Democratic Congress which had its elections from 17 November to 19 November 2018. The selected social media was Twitter because it is a popular platform among Ghanaians (Dzisah, 2020; Boateng, 2019; Gyampo, 2017).

The timeframe was set from the seven days leading up to their respective 2018 national executive elections, three days during those elections, and another seven days after the elections. Therefore, data were collected from the official Twitter platforms of the New Patriotic Party from 29 June to 5 July 2018 (7 days before); 6 July to 8 July 2018 (3 days during) and 9 July to 15 July 2018 (7 days after). For the National Democratic Congress data was collected from 10 November to 16 November 2018 ( 7 days before); 17 November to 19 November 2018 ( 3 days during) and 20 November to 16 November 2018 (7 days after). From Twitter, 16 tweets were recorded from the page of the New Patriotic Party, while the National Democratic Congress did five tweets over the period (See Table 1). The tweets collected from these two platforms of the political parties are in different formats, including videos, audio, pictures, texts, comments, likes, shares, replies, reactions and retweets. The data was captured by means of a screen captor (Microsoft Snipper Tool) for screenshots of tweets made by the two political parties during the different periods sampled. 


\section{Content analysis}

As Krippendorf (2004) and Babbie (2001) suggest, content analysis includes the coding of raw data into meaningful or standard forms. This could be in the form of coding acts with regard to underlining themes in the data that was analysed (Bryman, 2004). Content analysis was employed to quantitatively determine four categories of information from the data collected from Twitter according to a coding scheme. Using the coding scheme, dates of daily Twitter tweets, as well as their corresponding numbers of comments, shares, tweets, likes, replies and retweets were recorded. The research used the coding framework of Gong and Lips (2009), such as Information provision, Interactive chats, Multimedia and Targeted campaigning to explain how political parties adopt Twitter to engage with stakeholders in the public sphere, in campaigns, for dissemination and for retrieving information of different formats (Sauter \& Bruns, 2013).

Information provision messages draw the attention of audiences to news and events without attempts to seek feedback from audiences (Gong \& Lips, 2009), while interactive chats involve the exchange of texts, videos and audios in real time between participants in communication, which attempts to elicit a response, feedback and collaboration (SolarAdillon et al., 2016). Multimedia messages involve posts and tweets in picture, audio and video formats (Coulombe, 2004), while targeted campaigning messages focus on identified audiences and specific groups within the public (Gong \& Lips, 2009). Tweets in different formats are grouped under each of the four categories of Gong and Lips (2009). Under Gong and Lips' (2009) categories, this study coded tweets into news, press release or policy statements, or involved interactive chats, questions and answers or responses to enquiries, and whether these messages were pictures, audios or videos, or targeted specific voter segments and opponents. Data from content analysis of Twitter was quantified to determine the number of tweets made by the New Patriotic Party and the National Democratic Congress over the sampled period for discussion.

\section{DISCUSSION}

This section discusses data collected from the Twitter platforms of the two political parties to determine how they used one-way and two-way communication in relating with stakeholders and the public.

\section{Frequency of Tweets}

\section{The New Patriotic Party}

In the 2018 internal national executive elections of the New Patriotic Party, the party communicated 16 times on Twitter (Refer to Table 1). These messages on the platforms were made up of different formats, such as videos, audio and texts. Put together, the 16 tweets that represented diverse communication content categories, including information provision, interactive chats, targeted campaigning and multimedia messages (see Table 1: news/press releases, question/answer sessions, pictures/videos and opponents) on Twitter by the New Patriotic Party attracted 1543 likes, and 89 replies, which were retweeted 258 times, indicating endorsements by audiences of messages to other users and friends on the platforms.

\section{The National Democratic Congress}

The National Democratic Congress communicated 5 times (messages) in different formats on Twitter (see Table 1: news/press releases, question/answer sessions, pictures/videos and opponents) during the 2018 national executive elections. The 5 tweets made by the National Democratic Congress during the national executive elections (Refer to Table 1) attracted 1361 replies and 124 likes, which were retweeted 180 times by its followers on Twitter. 


\section{One-Way Communication}

\section{Information}

Most of the tweets made by the New Patriotic Party and the National Democratic Congress fell into the information provision category. Information provision messages draw the attention of audiences to news and events without necessarily eliciting responses from audiences (Gong \& Lips, 2009); this is typically one-way communication. Political parties put messages to inform or provide news to the public and citizens through social media. The New Patriotic Party tweeted two press releases and 12 news items to provide information to the public on Twitter during the sampled period in its 2018 national executive elections. On the other hand, the National Democratic Congress tweeted two news items but no press release on Twitter during its 2018 national executive elections. The New Patriotic Party posted 2 press releases, while the National Democratic Congress posted 3 press releases on their Facebook platforms.

The political parties tweeted messages, such as "Liberal Party, UPP, PPP and CPP all present solidarity messages @NPP Conference 2018," and "Report of the state of the party being delivered by Ag. General Secretary \#NPP Conference 2018," and "This is a single national delegate' congress in our history and it has been awesome. We are grateful to our members and supporters" (www.twitter.com) by the political parties on their Twitter platforms.

The National Democratic Congress and the New Patriotic Party used Twitter largely for the purposes of public information, that is, spreading their information and messages from their political parties to their stakeholders and the general public using press statements and news releases, and picture and video contents without eliciting responses or feedback from audiences. The focus on public information in the communication practices of the New Patriotic Party and the National Democratic Congress on Twitter challenges them in maximising their appropriation of these platforms for sustaining mutual engagements, conversations and relationships with stakeholders and the public for support. This consequently minimises the potential and utility of Twitter as a platform for giving stakeholders and users the chance to mutually maximise their political expressions, information and issues through interaction (Kearney, 2017). This is especially true because through the political appropriation of social media for engagement, communication and interaction, political parties are able to connect and directly or interpersonally relate with the public and many people globally.

\section{Two-Way Communication}

\section{Interactive Messages}

Interactive chats involve the exchange of texts, videos and audio in real time between participants in communication, which elicit feedback and promote collaboration (Solar-Adillon et al., 2016). For the 17 days sampled for each of the political parties, the New Patriotic Party and the National Democratic Congress did not tweet interactive chats on Twitter; that is two-way communication. The findings show that the New Patriotic Party and the National Democratic Congress failed to reply to comments and to address issues raised by recipients of their messages (tweets) on Twitter platforms during the sampled study period, preventing relevant and sustainable conversations. The political parties did not seem to be particularly concerned about addressing interaction-goals of their audiences in Twitter communication. As the National Democratic Congress and the New Patriotic Party do not particularly interact and converse on Twitter, it prevents them from using two-way symmetrical communication on social media, which Boateng et al. (2020), Dragaset (2014), Goncalves (2014) and Strömbäck and Kiousis (2014, 2013) argue are useful for political public relations and mutually beneficial relationships via political communication. 


\section{Multimedia Messages}

Multimedia messages include posts and tweets in picture, audio and video formats (Coulombe, 2004). The multi-media messages of the two political parties involve pictures and videos. For the 17 days sampled for each of the political parties, the New Patriotic Party tweeted 2 pictures, while the National Democratic Congress also tweeted 3 pictures on their Twitter platforms.

\section{Direct Targeting}

Targeted campaigning involves tweets that are targeted at identified audiences and specific groups within the public (Gong $\&$ Lips, 2009). Considering the categories of messages (Refer to Specific voter segments and Opponents in Table 1), the National Democratic Congress and New Patriotic Party did not use Twitter for targeted campaigning programmes and activities. During the 17 days sampled for each of the two political parties in their respective national executive elections in 2018, the New Patriotic Party made no tweets targeting their opponents or specific voter segments. Similarly, the National Democratic Congress did not tweet any messages that targeted political opponents or specific voter segments.

Despite the encouragement by scholars (Kearney, 2017; Hadji, 2016; Gonçalves, 2014; Strömbäck \& Kiousis, 2014, 2013) for the use of social media in influencing the public to achieve political goals by seeking opinions and feedback through interactions, neither the New Patriotic Party nor the National Democratic Congress transmit, and tweet their political messages and information on the platforms to exploit the maximum potential and utility of Twitter for interactions. This is so because these political parties could not exchange coherent messages to sustain conversations with stakeholders and the public in determining and addressing the expectations of people. These political parties could rather be more interested in creating or maintaining their presence and identities, profiling their organisations, members and leaders on Twitter without developing bonds and long-term relationships with the general public towards election campaigns.

Considering the findings of Dzisah (2020), Gyampo (2017) and Tettey (2017) on the significant transformation presented by social media to democracy and politics in Ghana, this article contradicts their assertions that political parties use social media frequently in communicating policies on key issues, including Twitter, as shown in the content categories of tweets on the sites (Refer to Policy Statement in Table 1). The recognition of the significance of social media has not been well accepted, or perhaps not put into maximum use by the New Patriotic Party and the National Democratic Congress as these political parties have not extensively exploited the full potentials of Twitter.

Given the categories of social media messages (Refer to Interactive chats, Questions and answer sessions and Response to enquiries in Table 1), the National Democratic Congress and the New Patriotic Party are not particular about soliciting the opinions, views and voices of stakeholders and the general public with respect to current and topical issues that might impede development in the country. This is contrary to the suggestion by Gyampo (2017) that social media provide users, citizens and supporters the opportunity to express their thoughts, opinions and views on political issues via conversations.

Given how the National Democratic Congress and the New Patriotic Party used Twitter in their respective national executive elections in 2018, these political parties and their communication officials may not have the political public relations competence and skills to appreciate the significance of mutually beneficial political communication and engagements through the use of interactive chats and conversations to establish relationships with the public and voters for 
election campaigns. This could contribute to the ad-hoc use of social media communication including Twitter in communication and electoral activities of the National Democratic Congress and the New Patriotic Party.

Given this, the article situates Twitter as a unique and convenient interactive platform to enhance interpersonal political engagements for the advancement of political agendas and campaigns. This is important because social media give users and political parties the opportunity to control the contents of their messages with no traditional intermediaries between engagements or interactive and interpersonal exchange of information. This is achieved through direct posts and tweets with the public and stakeholders for responses, conversations and mutually beneficial relationships. However, the minimal use of Twitter coupled with a lack of direct responses from political parties to users and public reactions, comments and feedback on messages disseminated makes it difficult to advance political agendas and campaigns through interpersonal engagements and interactions on the platforms.

Table 1: Categories of Twitter Content of the National Democratic Congress and New Patriotic Party

\begin{tabular}{|c|c|c|c|c|c|c|c|c|c|c|c|}
\hline \multirow{3}{*}{$\begin{array}{l}\text { Political } \\
\text { Parties }\end{array}$} & \multicolumn{11}{|c|}{ Content Categories } \\
\hline & \multicolumn{3}{|c|}{ Information Provision } & \multicolumn{3}{|c|}{ Interactive Chats } & \multicolumn{3}{|c|}{ Multimedia } & \multicolumn{2}{|c|}{$\begin{array}{c}\text { Targeted } \\
\text { Campaigning }\end{array}$} \\
\hline & News & $\begin{array}{l}\text { Press } \\
\text { Release }\end{array}$ & $\begin{array}{l}\text { Policy } \\
\text { statements }\end{array}$ & $\begin{array}{c}\text { Interactive } \\
\text { chats }\end{array}$ & $\begin{array}{l}\text { Question } \\
\text { and } \\
\text { answer } \\
\text { sessions }\end{array}$ & $\begin{array}{l}\text { Response } \\
\text { to } \\
\text { enquiries }\end{array}$ & Pictures & $\begin{array}{l}\text { Audio } \\
\text { content }\end{array}$ & $\begin{array}{l}\text { Video } \\
\text { content }\end{array}$ & $\begin{array}{l}\text { Specific } \\
\text { voter } \\
\text { segments }\end{array}$ & Opponents \\
\hline NPP & 12 & 2 & - & - & - & - & 2 & - & - & - & - \\
\hline NDC & 2 & - & - & - & - & - & 3 & - & - & - & - \\
\hline
\end{tabular}

Source: www.twiiter.com

\section{CONCLUSIONS}

The theoretical point of departure in the article was that political parties should emphasise relationship building in their political communication with citizens. This would imply that political communication should also include two-way communication to enhance the traditional one-way communication. The article argued that Twitter could improve interactive communication and engagements for support in political activities and election campaigns of political parties and therefore enhance the relationship between political parties and their constituents. Political parties in Ghana can especially use Twitter targeted at interactive engagements with stakeholders and the general public. Given the ability of social media to promote interpersonal communication across distance and location, audiences of messages on platforms could participate in interactive discussions with political parties to advance relationships and the long-term sustainability of the party. These social media could change how political engagements and campaign communication are conducted because political parties and citizens can mutually address issues in real-time for understanding and beneficial relationships. Against this background, it investigated how the New Patriotic Party and the National Democratic Congress used Twitter during their 2018 national executive elections.

From the research findings, this article concludes that political parties in Ghana have made efforts to use social media to connect with their followers and the public. However, the infrequent and minimal use of Twitter by the New Patriotic Party and the National Democratic Congress for passing information to the public does not enable them to enhance sustainable mutually beneficial relationships for support towards elections. The insignificant number of tweets by the political parties during the 2018 national executive elections provides evidence to suggest that political appropriation of social media in Ghana is still developing. Political parties are not maximising the potentials and usage of Twitter 
consistently to address topical issues and stimulate conversations with the public to posit them favourably with the public via the interactive features of the platforms. The research found that the New Patriotic Party and the National Democratic Congress use Twitter for one-way communication with stakeholders and the public. These political parties use Twitter to inform the public about their activities and programmes, rather than interacting with them to develop mutually beneficial relationships. The political parties made tweets infrequently to users and followers on Twitter. The National Democratic Congress and the New Patriotic Party need to improve their social media use, particularly Twitter, for engaging and interacting with users and the public to galvanise support of citizens, followers and supporters in advancing political agendas and election campaigns.

\section{REFERENCES}

1. Asah-Asante, K. (2015). Changing forms of political communication and voter choices in Ghana's elections from 1992-2008, Unpublished PhD Thesis, Department of Political Science, University of Ghana.

2. Babbie, E. (2001). The practice of social science research. Belmont, California: Wadsworth.

3. Beciu, C. (2011). Sociologia comunicării şi a spațiului public: Concepte, teme, analize. Polirom Publishing House, Iaşi.

4. Biswas, A., Ingle, N. \& Roy, M. (2014). Influence of social media on voting behaviour. Journal of Power, Politics and Governance, 2(2): 127-155.

5. Boateng, A., B. (2019). Facebook usage in political communication in Ghana: The case of two political parties, Unpublished PhD Thesis, Centre for Communication, Media and Society, University of KwaZulu-Natal, South Africa.

6. Boateng, A., B., McCracken, D., P. \& Lubombo, M. (2020). Intra-party election campaigns in Ghana: An analysis of Facebook use. In M., Ndlela and W., Mano (Eds.), Social media and electoral democracy in Africa, Volume 1: Theoretical perspectives and election campaigns. Cham: Palgrave Macmillan.

7. Borah, P. (2016). Political Facebook use: Campaign strategies used in 2008 and 2012 presidential elections, Journal of Information Technology \& Politics, 13(4): 326-338.

8. Bryman, A. (2004). Social research methods. New York: Oxford University Press.

9. Coulombe, S. (2004). Multimedia adaptation for multimedia messaging service, IEEE Communication Magazine, 42(7): 120126.

10. Cutlip, S., Center, A. \& Broom, G. (1994). Effective Public relations. Eaglewood Cliffs, New Jersey: Prentice-Hall.

11. Debrah, E. (2005). Political parties and democratic consolidation in Ghana from 1992-2004. Unpublished PhD Thesis: Department of Political Science, University of Ghana.

12. Denton, R., E., J., Trent, J., S. \& Friedenberg, R., V. (2020). Political campaign communication: Principles and practices. Maryland: Rowman and Littlefield.

13. Dillard, J., P. (2008). Goals-plans-action theory of message production. In L., A., Baxter and D., O., Braithwaite (Eds.), Engaging theories in interpersonal communication: Multiple perspectives. Los Angeles, California: Sage.

14. Drageset, D. (2014). Is symmetrical communication in politics possible? A comparative study of communication practices among New Zealand and Norwegian political public relations practitioners, MA Thesis: Auckland University of Technology. 
15. Dzisah, W. (2020). Social Media and Participation in Ghana's 2016 Elections. In M., Ndlela and W., Mano (Eds.), Social media and electoral democracy in Africa, Volume 1: Theoretical perspectives and election campaigns. Cham: Palgrave Macmillan.

16. Enli, G. (2017). Twitter as arena for the authentic outsider: exploring the social media campaigns of Trump and Clinton in the 2016 US presidential election. European Journal of Communication. 32(1): 50-61.

17. Gonçalves, G. (2014). Political public relations: Origins, challenges and applications, Comunicação e Sociedade, 26, 99-107.

18. Gong, H. \& Lips, M. (2009). The use of new media by political parties in the 2008 national elections. Retrieved on 18 October 2019 from: http://e.government.vuw.ac.nz/research_projects_2009/eCampaigning_NZ_2008.pdf.

19. Grunig, J., E. (2001). Two-way symmetrical public relations-past, present and future. In R., L. Heath and G., Vasquez, (Eds.), Handbook of Public Relations. Thousand Oaks, California: Sage.

20. Gyampo, R., E., V. (2017). Political parties and social media in Ghana. Africology: The Journal of Pan African Studies, 10(1): 186-205.

21. Hadji, A. (2016). Breaking boundaries: The opportunities for using social media in civil society networking, activism and civic engagement. In M., Kamp, M., (Ed.), Assessing the impact of social media on political communication and civic engagement in Uganda. Uganda Programme, Konrad Adenauer-Stiftung.

22. Hoffmann, C., P. \& Suphan, A. (2017). Stuck with "electronic brochures"? How boundary management strategies shape politicians' social media use. Information, Communication \& Society, 20(4): 551-569.

23. Kalsnes, B. (2016). The social media paradox explained: Comparing political parties' Facebook strategy versus practice, Social Media and Society, 2(2): 1-11.

24. Kearney, W., M. (2017). Interpersonal goals and political uses of Facebook, Communication Research Reports, 34(2): 106114.

25. Kiyohara, S., Maeshima, K., \& Owen, D. (Eds.). (2018). Internet election campaigns in the United States, Japan, South Korea and Taiwan. Cham: Palgrave Macmillan.

26. Klingemann, H., D. \& Römmele, A. (Eds.). (2002). Public information campaigns and opinion research: A handbook for the student and practitioner. Thousand Oaks, California: Sage.

27. Kreiss, D. (2016). Seizing the moment: The presidential campaigns' use of Twitter during the 2012 electoral cycle. New Media \& Society. 18(8): 1473-1490.

28. Krippendorf, K. (2004). Content analysis: An introduction to its methodology (2 ${ }^{\text {nd }}$ Ed.), Thousand Oaks, California: Sage.

29. Larsson, A., O. (2015). Green light for interaction: Party use of social media during the 2014 Swedish election year. First Monday, 20(12).

30. Lilleker, D., G. \& Jackson, N., J. (2011). Political Campaigning, Elections and the Internet. Comparing the US, UK, France and Germany. London: Routledge.

31. Mayfield, A. (2008). What is social media? iCrossing. Retrieved from www.icrossing.co.uk/.../What_is_Social_Media_iCrossing_ebook.pdf.

32. Muhingi, W., N., Agonga, A., Mainye, M., M., Mong'are, A., B. \& Maranga, F., K. (2015). Political communication for sustainable development in Kenya. Developing Country Studies, 5(18): 57-64. 
33. Mutsvairo, B. \& Ragnedda, M. (2019). Does digital exclusion undermine social media's democratising capacity? New Global Studies, 13(3): 357-364.

34. Ndlela, M., N. \& Mano, W. (Eds.). (2020). Social media and electoral democracy in Africa, Volume 1: Theoretical perspectives and election campaigns. Cham: Palgrave Macmillan.

35. Oye, A. (2009). Issues of images? Content analysis of television political advertisements in the 2008 elections in Ghana. Unpublished Master's Thesis, School of Communication Studies, University of Ghana.

36. Penplusbytes (2017). Social media and political campaigning in Ghana. Retrieved on 10 October 2017 from www. penplusbytes.org.

37. Perloff, R., M. (2014). Social media effects on young women's body image concerns: Theoretical perspectives and an agenda for research. Sex Roles, 71(11/12): 363-377.

38. Riaz, S. (2010). Effects of new media technologies on political communication, Journal of Political Studies, 1(2): 161-173.

39. Sandoval-Almazan, R. \& Gil-Garcia, J., R. (2014). Towards cyber activism 2.0? Understanding the use of social media and other information technologies for political activism and social movements. Government Information Quarterly, 31(3): 365378.

40. Sauter, T. \& Bruns, A. (2013). Exploring emotions on \#auspol: Polarity, conservativism and public performance in the Twitter debate on Australian politics. Selected papers of Internet Research, 14.

41. Soler-Adillon, J., Sora, C., Freixa, P. \& Joan-Ignasi, R. (2016). Perfil del professional de la communicacion interactive: Fundamtentos, actualidad y perspectivas. El Profesional de la Informacion, 25(2): 196-208.

42. Strömbäck, J. \& Kiousis, S. (2014). Strategic political communication in election campaigns. In C., Reinemann (Ed.), Political communication. Berlin: Mouton de Gruyter.

43. Strömbäck, J. \& Kiousis, S. (2013). Political public relations: Old practice, new theory-building. Public Relations Journal, 7(4): 1-17.

44. Tettey, W. (2017). Mobile telephony and democracy in Ghana: Interrogating the changing ecology of citizen engagement and political communication. Telecommunication Policy, 41(5/6): 685-694.

45. Volders, S. (2013). Agenda-setting theory in political discourse on Twitter: A case study on traditional media influence within a popular citizen journalism medium, Unpublished Master's Thesis, Tilburg University, Tilburg.

46. Windeck, F. (2011). Political communication in Sub Saharan Africa and the role of new media. Retrieved on 25 August 2019 from www.kas.de/wf/doc/ka.

47. Shukla, Neha. "Social Media \& Its Influence on Customer Relationship in Indian Retail Scenario." International Journal of Sales \& Marketing Management Research and Development (IJSMMRD) 7.4: 27-34.

48. Jayaram, B., et al. "A Survey On Social Media Data Analytics And Cloud Computing Tools." International Journal of Mechanical and Production Engineering Research and Development, 8 (3), 243254.

49. Katz, Yaron. "Social Media Is Powerful, but Can It Change Policies of Institutionalized Organizations Such as the Israeli Army?." International Journal of Humanities and Social Sciences (IJHSS) 6.6: 29-34.

50. Khan, M. S., et al. "Effect of social media on enhancement of English learning proficiency at university level in Khyber Pakhtunkhwa." Journal of Humanities and Social $\quad$ Sciences 2.2: $\quad$ 71-84. 
